\title{
Sustainable Development at an Individual Level: The Key to Sustainable Textiles and Fashion
}

\author{
Miguel Angel Gardetti* \\ Sustainable Textil Center, The Center for Studies on Sustainable Luxury, director, Argentina
}

Submission: September 28, 2017; Published: November 13, 2017

*Corresponding author: Miguel Angel Gardetti, Director, Sustainable Textile Center, The Center for Studies on Sustainable Luxury, Argentina, Email: mag@sustentabilidad.org.ar

\section{Introduction}

We have always argued that the concept of sustainability invites us to set aside our ideological and institutional assumptions and address global problems and needs with a sense of humility. The size of the sustainability challengesand, therefore, the potential opportunities for progress-exceed anything that has been faced in the history of mankind. Today, the major challenge is to strike a reasonable balance between usually conflicting issues. And, in the process of striking a reasonable balance, all sectors of society must learn to co-exist and, indeed, to actively collaborate if catastrophe is to be averted and a more ecologically sustainable, socially equitable and economically stable world is to be achieved for a world of up to 9 billion people in the coming decades. And the textile and fashion sectors are not spare from this.

Many authors and organizations have analyzed the impact of the textile and fashion industry. Some of them include Slater K (2000), Allwood et al. [1], Fletcher [2], UK Department for Environment, Food and Rural Affairs [3], Ross [4], Dickson et al. [5], and Gwilt \& Rissanen [6]. From a sustainability view, many times this industry operates to the detriment of environmental and social factors. The textile industry uses large quantities of water and energy (two of the most pressing issues worldwide), in addition to building waste, effluents and pollution. Both textile-fashionable or not fashionable- product manufacture and consumption are significant sources of environmental damage. As to social aspects, non-qualified jobs have been lost in regions that mostly relied on these industries. Another serious and still unresolved problem is the increasing flexibility textile and clothing industry companies need. Faced with fierce international competition, these companies find it more and more difficult to ensure job tenure. Let alone, the clandestine work proliferating both in developing and developed countries. Child labor continues being a fact in this sector despite the trend to reverse it thanks to the growing pressure of different agencies. In turn, fashion, in its worst form, encourages overconsumption, promotes shallow values to reach happiness, and also makes consumers feel stressed and insecure while causing very harmful effects on health such as bulimia and anorexia.

To fully commit both industries to the transition towards sustainability, we need to make a critical review of our thinking and our practices, and to develop a feasible vision and alternatives. That is, we need to engage in a thorough thinking process. However, this opportunity should be taken and realized from a sector and organization perspective, and even more deeply, from an individual perspective.

Sustainable development is a notion of the world deeply different from the one that dominates our current thinking, and includes satisfying basic human needs such as justice, freedom, and dignity [7]. It is the vision through which we can build a different way of being (Ehrenfeld, 2002). We need to move away from purely objective and "rational" reasoning to consider the spiritual (...), and pragmatic [8]. In other words: to live by love, happiness or sustainability involves acquiring certain ethical values, and mental and spiritual openness, and putting in practice what we want to live [9]. Social illnesses, such as ambition, depression, envy or addictions, prevent us from discovering or taking our own place to help our world grow. We have to look for "meaning" and "deep values" [10]. According to André L. Delbecq in his work willing to be God's Fool (2007), we should develop the virtues of humility, gratitude, and respect for others, as well as to acknowledge the greatness of this world and everything in it. He was not the first to note it: Martin Luther King Jr. (1959) referred to being humble, responsible, and active when doing our share. As explained by Doppelt [11], to discuss Sustainability, we should keep an open mind, starting with basic values in line with the ethics that we expect for the world that we wish to create: it means to move from "me" to "we" [11]. And it is here where "they" become essentially relevant [12]. And in this critical examination we might ask ourselves: 
1. As a society

What do these two industries exist for? Who is/are their intended audience/s? Who do they benefit? Why does economic gain prevail to the detriment of the environment and human beings? And, more broadly, what do we expect from them as citizens?

\section{As Industry Professionals}

What are the expectations of workers and professionals in these industries? How can fashion be designed and produced so that we can thrive as human beings?

\section{For Industries and Ventures}

Which business models foster sustainability values? How can a textile or fashion company be holistic and interconnected in a world that demands more and more transparency?

Sustainability in textiles and fashion requires more than reducing or eliminating the above impacts $[13,14]$. The analysis and subsequent response to these questions would also help fashion and textiles become a vehicle to improve living conditions, as well as to teach and convey values both within and outside the family. Moreover, they can also become a tool for dialogue between nations. Fashion and textile sustainability becomes meaningless if it fails to consider the personal reality of human beings. It is a matter of values and their relationship with virtues.

\section{References}

1. Allwood JM, Laursen SE, Malvido de RC, Bocken NMP (2006) Well dressed? The present and future sustainability of clothing and textiles in the United Kingdom (Cambridge, UK: University of Cambridge, Institute for Manufacturing).

2. Flechter K (2008) Sustainable Fashion and Textiles Design Journey (London, UK: Earthscan).
3. UK Department for Environment, Food and Rural Affairs-DEFRA (2008) Sustainable clothing roadmap briefing note December 2007: sustainability impacts of clothing and current interventions (London, UK: DEFRA).

4. Ross RJS (2009) Slaves to Fashion: Poverty and Abuse in the New Sweatshop (Ann Arbor, USA: The University of Michigan Press).

5. Dickson MA, Loker S, Eckman M (2009) Social Responsibility in the Global Apparel Industry (New York, USA: Fairchild Books).

6. Gwilt A, Rissanen T (2011) Shaping Sustainable Fashion - Changing the Way we make and Use Clothes (London, UK: Earthscan).

7. Ehrenfeld JR (1999) Cultural Structure and the Challenge of Sustainability. In Sexton, Ken; Marcus, Alfred A.; Easter, K. Williams y Burkhardt, Timothy D. Better Environmental Decisions-Strategies for Governments, Businesses, and Communities. Washington, Island Press, USA pp. 223-244.

8. Ehrenfeld JR, Hoffman AJ (2013) Flourishing-A Frank Conversation about Sustainability. Sheffield: Greenleaf Publishing.

9. Ehrenfeld JR (2008) Sustainability by Design. New Haven: Yale University Press, USA.

10. Rimanoczy I (2013) Big Bang Being-Developing the Sustainability Mindset. Sheffield: Greenleaf Publishing, UK.

11. Doppelt B (2012) To Us From Me-The Five Transformational Commitments Required to Rescue the Planet, Your Organization, and Your Life (Sheffield, UK: Greenleaf Publishing).

12. Gardetti MA (2017) Speech at the presentation of the book titled "Textiles y Moda: ¿Quéessersustentable?." Activity conducted at IDES, Buenos Aires, Argentina.

13. King ML (1959) The Measure of Man. The Christian Education Press, Philadelphia, US.

14. UK Department for Environment, Food and Rural Affairs -DEFRA(2008) Sustainable clothing roadmap briefing note December 2007: sustainability impacts of clothing and current interventions (London, UK: DEFRA).

\section{Your next submission with Juniper Publishers} will reach you the below assets

- Quality Editorial service

- Swift Peer Review

- Reprints availability

- E-prints Service

- Manuscript Podcast for convenient understanding

- Global attainment for your research

- Manuscript accessibility in different formats

( Pdf, E-pub, Full Text, Audio)

- Unceasing customer service

Track the below URL for one-step submission https://juniperpublishers.com/online-submission.php 